\title{
Montreal 2008
}

\author{
By Christina Stojanova
}

Fall 2008 Issue of KINEMA

\section{MORAL TALES FROM THE MONTREAL WORLD FILM FESTIVAL}

The Competition selection of the $32^{\text {nd }}$ Montreal International Film Festival (21 August - 1 September 2008) featured twenty fiction films, at least one third of which were well-crafted exemplars of mainstream "cinema of quality" in the best sense of the term. In a way, films like Faubourg 36, Farewell Gulsary, Welcome to Farewell-Gutmann, The Necessities of Life, and to a great extent, Theo's Voyage, seek to update or popularize the stylistic or genre traditions they are made in, whether national or international, without shunning from emotions that often venture into the melodramatic and even the sentimental, or from predictable plot twists meant to keep the viewers both on edge and to please their instinct for imitation, and of anticipated reversals and recognition as Aristotle would have it. Beneath and beyond the emotional excess, displayed in these films, "there lies," as Peter Brooks writes in his study The Melodramatic Imagination, a "centre of interest which is the scene of the underlying drama," or the "moral occult." It is the "domain of operative spiritual values. Both indicated within and masked by the surface of reality" since in his view, melodrama emerges as a "response to the loss of traditional values" in times of social or cultural crisis. In this sense, the above films allow for a glimpse into these hidden "spiritual values" and their interaction with reality, past and present.

The opening film of the festival, Christophe Barratier's Faubourg 36 (Paris 36) is a case in point in his ambitious return to the high emotionalism and stark ethical conflicts of the French popular cinema from the 1930s. Following the success of his previous Oscar-nominated film Les choristes (The Choir, 2004), the director brings up to date this historical tradition, somewhat overshadowed by the long lasting fame of the nouvelle vague. Situated in a working class neighbourhood of Paris at the time of the brief success and proletarian optimism of Le Front Populaire in 1936, the film employs open references to René Clair's political musicals (Sous les toits de Paris, 1930, À nous la liberté 1931); to the intricate love affairs of Marcel Carné's actors in Les enfants du paradis (1945); to the lavishly designed show-stoppers of Busby Berkeley's musicals and even a quote or two from Singin' In the Rain (1952, Donen \& Kelly). Unfortunately this intertextual richesse of style weighs somewhat heavily on the otherwise charming melodramatic story about the eternally redemptive power of love and music on the backdrop of aggravating social tensions, growing anti-Semitism and a looming WWII.

The entry from Kazakhstan, Farewell Gulsary (Porshai Gulsary) by Ardak Amirkulov is yet another nostalgic narrative, both in tenor and mode. Based on a short story by famous Kyrgyz author Chingiz Aitmatov, it is about the love of the main character, a devout Kazakh communist and a WWII hero, for his beautiful stallion Gulsary, who is of course a symbol of freedom and idealism - everything the main character stands to lose to crash collectivization and its Stalinist apparatchiks in the Far East.

Amirkulov's film is undoubtedly inspired by the intricate metaphoric language of Soviet poetic cinema from the 1970s, associated with such masters as Sergei Parajanov, Otar Iosseliani, Yuri Ilyenko, where escapist indigenous motifs - ecological and mythological - suppressed by Communism, stood for oblique criticism of the oppressive system. By openly exposing the devastation, inflicted by the artificially imposed Soviet modernity on the traditional way of life, Farewell Gulsary responds to the "loss of traditional values" by sentimentalizing the high canon of Soviet poetic cinema, and by foregrounding the "operating spirituality... masked" by the harsh reality - past and present - amongst the barren Kazakh steppes. Along with Guka Omarova's Baksy (2008) and Sergei Dvortsevoy's Tulpan (2008), Amirkulov's melancholic narrative is yet another highlight in the string of the most recent successes of Kazakh cinema.

The French Canadian entry, The Necessities of Life (Ce qu'il faut pour vivre, awarded Special Grand Prix of the Jury; Public Award for the most popular film of the Festival and Public Award for the most popular Canadian Feature Film) - the first fiction film of Quebec documentary filmmaker Benoit Pilon, is also a period film, situated in Quebec circa early 1950s. Starring famous Inuit actor Natar Ungalaaq (Atanarjuat: The Fast Runner, 2001) as Tivii, it, too, seeks wider conciliatory response to "sensitive spiritual values" 
operating beneath the surface of the uneasy relations between the Inuit of the Quebec North and the FrenchCanadian majority, that have so far been the domain of sharp media criticism focusing on unresolved land claims and the abuse of Aboriginal children at the Catholic Church-run residential schools.

Pilon tells his story of the clash of traditions and survival in a culturally alien environment in an emotionally heightened manner. Which is inevitable since the action takes place in a hospital for TB patients in Quebec City, run by Catholic nuns. Tivii is devastated by his indefinite hospitalization and his total cultural and linguistic isolation, away from his beloved family and life as a hunter and provider of what, in his words, are the eponymous "necessities of life: seals, caribou and geese." The most gripping plot line, thanks to the superb acting of the trio, is the friendship Tivii develops with nurse Carole (Eveline Gélinas) and the terminally ill Khaki (Paul-André Brasseur). The young Inuit boy becomes his lifeline by translating for him, but dies just when Tivii succeeds in his plans to adopt and raise Khaki as Inuit. The director reveals the "moral occult" of the "underlying personal and social drama" in building a solid background, where everyone, even the ward bully, is humbled by the constant presence of death thus containing (or normalizing?) latently explosive ethnic tensions within the terrain of the Canadian cinematic tradition of representing cultural incongruities in an elegantly humorous, but respectful manner.

A less successful attempt to mediate a social crisis in melodramatic terms is offered by the Mexican film, Theo's Voyage (El viaje de Teo by Walter Doehner, 2007, Best Actor award for Eri Cañete as Teo and Special mention of the Ecumenical jury). Structured as a road movie, it shows the plight of Mexicans illegally crossing the US border through the eyes of nine-year-old Theo, who leaves behind the security of his uncle's home to join his father, an ex-convict and virtuoso trumpet player, on what turns out to be his fatal journey up north, where he hopes to join his wife, Theo's beautiful mother, who works there illegally as a domestic. Quite predictably even for its genre, the film glosses over its socially tragic potential, highlighting moments of coincidental solidarity and last minute rescues, to tie up all its ends neatly in the happy reunion of mother and son in their native village. What brings this modest film above the average however is the growing significance of the father's trumpet Theo so desperately clings to. A prop initially, it gradually turns into a symbol of the "spiritual values" operating beneath the surface of the boy's life - his love for his family and friends, for music, for life... Which in our materialist times is more than one could expect from a mainstream movie.

The Spanish Welcome to Farewell-Gutmann (Bienvenido a Farewell-Gutmann, directed by Xavi Puebla, Best Screenplay Award), displays a similar penchant for didacticism, although it is not a melodrama. Quite the opposite - it belongs to a relatively new genre, born by post-modern anxieties and cynicism, which could be defined as an office grotesque, and has been best exemplified so far by Office Space (Mike Judge, 1999, USA), Waydowntown (Gary Burns, 2000, Canada), Smoking Room (Julio Wallovits, Roger Gual, 2002, Spain). Without much ado, the film introduces us to its premise and in a couple of broad strokes outlines its dramatis personae. Three popular office types - two males and one female - are competing for the recently vacated high position in their prosperous pharmaceutical company Farewell-Gutmann.

The calculated predictability of this message-driven narrative is sustained by its meticulous architectonic structure. An ambitious and conniving womanizer; a recovering alcoholic who wants his lost family and status back; and a divorcee workaholic, whose son is mentally retarded are determined to do anything but secure the job. In addition, the womanizer and the workaholic are engaged in an office romance, relegated strictly to sex and precluding any other commitments - emotional or ethical. While the battle for the top job is waged, the three main characters are symmetrically engaged in interviewing three applicants for lesser positions in the firm.

A process, which serves as additional litmus test of their dubious ethics and as yet another source of aesthetic pleasure. In order to fully meet the requirements of this tongue-in-cheek moralité, the narrative is supplied with a Lucifer-like personage, a headquarters' representative, who is putting to the test in a perfidiously sinister way the loyalties of the threesome to themselves and to others. His rewards and punishments are therefore allocated according to the fairness of their own approach to those less fortunate, in tune with the saying "what goes around, comes around" and thus - without any melodramatic excess - exposing neglected spiritual values and their devastating operating power.

On this backdrop, two films stood out - the Japanese Departures (Okuribito by Yojiro Takita) and The Tour 
(Turneja, by Goran Marković, Serbia-Bosnia and Herzegovina), the former picked the festival main award, Grand prix des Americas, and the latter - the FIPRESCI award as well as the Best Director Award.

And if the melodramatic narratives, discussed above, could be also defined as failed tragedies or tragedies in low mimetic mode (Northrop Frye), whose characters are like us or worse (Aristotle), then in the tragic narratives of Departures and The Tour, where ethical considerations prevail over the pathetic, the characters could be defined as better than us in degree because of their artistic vocation. The domain of the arts has arguably remained the only spiritual universe left untouched by the materialist impetus of our civilization, and artists - actors, musicians, painters - still enjoy what is left of the awe once reserved for sages, mystics and priests. But artists are increasingly expected to reach far and beyond their ivory towers and shoulder the problems of their troubled societies. The hero of Departures, for example, an unsuccessful and infantile cellist, finally finds his real calling at a funeral parlour performing the traditional ritual of preparing the dead for their final journey. Yet his unpopular but much-loved and socially useful job makes him an astute human being and a mature artist, capable of experiencing the real joy of art for art's sake.

Interpreting one of the most harrowing episodes in the recent history of former Yugoslavia - the war in Bosnia in 1993 - through the eyes of six actors on an ill-designed tour across the belligerent zone, serves as the backbone of The Tour by writer-director Goran Marković. Evidently, he has been inspired by such renowned works based on the incongruous presence of actors in war zones like Theo Angelopoulos's The Travelling Players (O Thiasos, 1975), where a group of Greek comedians crisscrosses their war-torn country from the late 1930s through the early fifties, or the much closer to home For Ever Mozart by Jean-Luc Godard (1996), featuring actors mounting a performance of a French comedy amongst the rubble of Sarajevo in the mid-nineties.

Marković' film however takes an important step further by initiating a process of (inter) national reconciliation and redemption. He therefore focuses on the actors' movement from utter ignorance about a war that seems so distant from their small Belgrade theatre, to first-hand knowledge of its universal bestiality. And what is more - to a painful realization of their moral responsibility and guilt by proxy. There are no bystanders in war and lack of spiritual commitment inevitably condemns artists to the mire of creative destitution.

To ensure a powerful cathartic experience for the viewers and facilitate their own voyage to enlightenment, Marković construes his theatre troupe archetypically: an aging diva, an ingénue, two male leads - one young and one old, a comedian, and the inevitable jack-of-all-trades. The diva is played by the Croatian theatre and movie star Mira Furlan, the sex-symbol of the generation fighting the war, and the ingénue by the charming Jelena Dokić, also Croatian, while the male cast is all Serbian. Dragan Nikolić, the legend of Yugoslav cinema since the late 1960s, appears as the jaded thespian, who has seen better days; popular TV actor Josif Tatić is the perennially drunk fatso, in charge of comic relief roles, and young Gordan Kičić is the romantic lover. And finally, well-known actor and producer Tihomir Stanić is the perennial loser, ineffective both on and off stage as entrepreneur of this unfortunate tour to the front lines of the war. Meticulously selected with ethnic and cultural self-referentiality in mind, this dream cast (including the producer, the famous Makavejev actor Svetozar Cvetković in a small role) is a nostalgic intertextual reminder of the thriving Yugoslav cinema as arguably one of the few truly federal institutions of Former Yugoslavia, and of the fellowship of its actors and actresses as an example of ethnic and religious tolerance.

The plot-driven narrative is designed architectonically and is therefore pleasurably predictable. After its departure from Belgrade in a weird multi-purpose paramilitary vehicle along the corridor to Krajina, the Serbian enclave in Bosnia and Herzegovina, the troupe repeatedly escapes death in the hands of all the belligerent factions, who look surprisingly identical: the Serbian army, the Croatian army, the Serbian Chetniks and the Muslim insurgents all sport the same war fatigues, speak the same language, and what is remarkable - share the same admiration for the actors they have grown up watching on TV and in cinemas.

Initially, the actors naively believe they could get away from this inferno not only with their lives but also with a round sum of money, in exchange for their rather lame performances of a boring comic play with Serbian nationalist content. Increasingly however, their physical survival comes to depend on the quality of their acting, which turns out to be the biggest challenge for this spoiled, cynical and mostly uninspired lot. Kicked out in the cold and later detained by the Croatian army, they put their lives in the hands of the 
Croatian diva and her clumsy attempts to muster some charming smiles along with excerpts from a Croatian nationalist lore to please the commander. She however fails to impress him and when the troupe is just about to meet a most horrible death in the mine-fields ahead, the Chetniks come to the rescue.

Which again turns to be a mixed blessing as the crazed Chetnik commander makes them watch and sing while a Croatian solder gets blown up by a mine. Their hopes are propped up soon after when treated to a royal welcome in the fortress-like home of a war profiteer, a typical representative of the only winners in this ludicrous war. But Zaki the fatso blows it all by an alcohol-inspired improvisation: in paradoxical anticipation of more booze, he bravely lets their nouveau rich host know what he really thinks of his prosperity, his wife and himself. And when the bodyguards jump on him, he screams "Do not beat me, I am only an actor," parodying István Szabó's prototypical conformist, Hendrik Höfgens, the star of the Third Reich theatre (Mephisto, 1981, Hungary) and his fickle attempts to exonerate his moral frailty in the name of art.

The troupe's artistic investment finally rises to the occasion when, surrounded by determined Muslim fighters and in the face of inevitable death, the ingénue recites passionately a monologue from Euripides' Iphigenia. Her superb delivery of a text prophetically relevant to the country's situation suggests eloquently that real art is indeed a question of life and death. And while Jadranka's moving performance secures the troupe's safe passage to Belgrade, the servile nationalist poetry of the second rate Serbian writer who has joined them on the road takes him directly to the firing squad.

The Tour is strongly reminiscent of yet another great film of a Serbian director, Slobodan Sijan's Ko to tamo peva (Who's Singing Over There? 1980), and winner at the Montreal World Film Festival. Its characters, a socially and ethnically mixed bag of passengers on board the rickety bus of Krstić \& Son, are also travelling to Belgrade on the eve of a major catastrophe - the beginning of WWII. Unlike Marković's troupe, however, they remain oblivious to the pending disaster and, while engulfed in petty divisive idiosyncrasies and quarrels, become surprisingly unanimous in victimizing the two Gypsy musicians on the bus. When the Germans bomb them into smithereens, the Gypsies are the only ones to survive, encapsulating the moral of the film in their final song, sadly foreboding of events yet to come:

Misfortune is my childhood lot

And in suffering I sing my song,

Wishing, oh my mother dear

That a dream was all this here

Sijan's musicians and Marković's actors endure because their art obliges them to see through the domain of spiritual values and into the future, enhancing the redemptive power of their and our cathartic experience, "purging us of our emotions and reconciling us to our fate" (Aristotle). The troupe does return to the safety of their theatre, deeply shaken and transformed by the initiating voyage, but there is something ominously foretelling when Djuro, the driver (Slavko Stima) refuses the invitation to spend the night in Belgrade with them: "I don't like your Belgrade," he says. The year is still 1993, almost six years away from the bombings in March 1999.

\section{Author Information}

Christina STOJANOVA teaches at the Department of Media Production and Studies at the University of Regina, Canada. She has contributed to Cine-bulles, KinoKultura, and the Montreal Gazette. Her publications include chapters in Berlin Culturescapes, Making it Like a Man: Canadian Masculinities, Eastern European Cinema, Traditions in World Cinema, Horror International, Alternative Europe and Cinema and Globalization. 